\title{
Penerapan Model Pembelajaran Problem Solving Berbasis Demonstrasi terhadap Peningkatan Hasil Belajar Siswa pada Materi Suhu dan Pengukurannya
}

\author{
I'ip Andella ${ }^{1}$, I. Kusumawati ${ }^{2}$, Eka Murdani ${ }^{3}$ \\ STKIP Singkawang, Singkawang, Indonesia \\ lipandela72@gmail.com ${ }^{1, *)}$, intank@stkipsingkawang.ac.id ${ }^{2}$, ekamurdani@gmail.com \\ ${ }^{*}$ Corresponding author
}

\section{Kata Kunci:}

Problem Solving Hasil Belajar;

Pengukurannya

\section{ABSTRAK}

Penelitian ini bertujuan untuk mengetahui hasil belajar siswa setelah diterapkan model pembelajaran problem solving berbasis demonstrasi pada materi suhu dan pengukurannya. Penelitian ini diadakan di kelas VII SMP Torsina Singkawang. Jenis penelitian ini adalah penelitian kuantitatif dengan bentuk pre experimental design dengan rancangan one group pre-test post-test design. Langkah awal penelitian, siswa diberi pre-test dilanjutkan dengan treatment berupa model pembelajaran problem solving dengan jangka waktu tertentu, langkah akhir diberikan post-test dan lembar respon siswa. Ditemukan bahwa hasil post test lebih tinggi dari hasil pre test yaitu hasil ratarata 38,69 menjadi 72,60. Peningkatan hasil belajar siswa dihitung dengan menggunakan rumus $\mathrm{N}$-gain dengan hasil nilai sebesar 0,55. Analisis data tersebut menunjukan terjadi peningkatan hasil belajar setelah diberikan perlakuan dengan model pembelajaran problem solving berbasis demonstrasi pada materi suhu dan pengukurannya.

\section{PENDAHULUAN}

Tujuan dari pendidikan Ilmu Pengetahuan Alam (IPA) yang termuat pada Peraturan Menteri Pendidikan Nasional Republik Indonesia Tentang Standar Isi Nomor 22 Tahun 2006, "Pendidikan berfungsi untuk mengembangkan kemampuan dan potensi yang dimiliki siswa agar menjadi manusia yang mandiri dan kreatif serta berakhlak mulia". Berkembangnya ilmu pengetahuan secara dinamis disinyalir berdasarkan Kurikulum Tingkat Satuan Pendidikan (KTSP) yang sudah diarahkan dengan tepat untuk menerapkan perkembangan seutuhnya. Pada KTSP, fisika sudah tercantum sebagai bagian dari Ilmu Pengetahuan Alam (IPA). Fisika merupakan satu di antara kajian bidang dari IPA atau sains yang mempelajari peristiwa dan gejala-gejala yang terjadi di alam semesta, sehingga fisika dapat dikatakan sebagai fondasi teknologi yang cukup beralasan untuk diberikan pada siswa sebagai bekal dalam menghadapi hidup di masa mendatang. Dengan demikian, dalam mempelajari fisika diperlukan penekanan pada pemahaman daripada penghafalan, yaitu pemahaman konsep yang lebih dititikberatkan pada proses terbentuknya pengetahuan oleh siswa. 
Satu di antara pelajaran fisika yang wajib dipelajari siswa SMP pada semester satu adalah suhu dan pengukurannya. Suhu dan pengukurannya adalah konsep fisika yang memiliki aplikasi yang luas dalam kehidupan sehari-hari. Namun demikian, pada kenyataannya tidak sedikit siswa yang mengalami kesulitan dalam menguasai konsep tentang suhu dan pengukurannya serta mengaplikasikannya dalam kehidupan sehari-hari. Berdasarkan hasil pengamatan pada proses pembelajaran fisika di kelas VII SMP Torsina Singkawang tahun ajaran 2014/2015. Ditemukan hasil belajar ranah kognitif siswa masih tergolong rendah. Hal ini dapat dilihat dari skor rata-rata ulangan harian kelas VII SMP Torsina Singkawang belum memenuhi Kriteria Ketuntasan Minimal (KKM) yaitu skor rata-rata hasil belajar ranah kognitif adalah 51,75 sedangkan KKM yang ditentukan sekolah adalah 65,00. Adapun yang dianggap menjadi akar permasalahannya adalah kualitas pembelajaran seperti: (a) Pembelajaran kurang melibatkan siswa, (b) Pembelajaran kurang membekali siswa dengan materi ajar. Hal ini diketahui dari aktivitas siswa yang sulit mengikuti pembelajaran secara optimal. Metode yang digunakan guru dalam pembelajaran fisika masih banyak menggunakan metode ceramah. Percobaan masih jarang dilakukan karena tidak ada laboratorium fisika sehingga sulitnya guru untuk memeroleh media atau alat pembelajaran, guru fisika beranggapan bahwa menggunakan metode ceramah dapat mencapai tujuan pembelajaran sehingga respon siswa ketika mengikuti proses pembelajaran masih terlihat pasif. Laboratorium perlu dilestarikan dan dikelola, karena berperan untuk mendorong efektivitas serta optimalisasi proses pembelajaran (Azizah \& Edie, 2014).

Pada proses pembelajaran yang demikian kemampuan siswa hanya tampak dalam menghafal faktafakta, rumus-rumus sehingga siswa tidak memahami secara mendalam subtansi materinya. Kesulitan lain yang akan timbul adalah siswa kurang mampu berperan aktif dalam mengemukakan ide-ide atau gagasan, kurang berinteraksi baik antara siswa dengan guru maupun siswa dengan siswa serta belum dapat menyelesaikan suatu persoalan di dalam kelas. Kondisi ini menyebabkan kemampuan berpikir siswa tidak berkembang karena siswa tidak dilibatkan dalam perolehan pengetahuan. Siswa mengalami kesulitan dalam pertanyaan yang memuat problem solving dalam instrument tes yang diberikan (Khoiri, Kusumawati, Kahar, \& Mursidi, 2019). Satu di antara upaya untuk meningkatkan hasil belajar siswa adalah dengan meningkatkan kualitas pembelajarannya, yaitu dengan menerapkan model pembelajaran problem solving berbasis demonstrasi. Pembelajaran dengan membimbing siswa untuk bersama-sama terlibat aktif dalam mengamati proses, informasi, peristiwa, alat dalam pembelajaran tersebut dan mampu membantu siswa bagaimana cara menghadapi persoalan dengan langkah penyelesaian yang sistematis yaitu dengan memahami masalah, menyusun rencana penyelesaian, melaksanakan perencanaan dan melihat kembali penyelesaian. Oleh karena itu, orientasi proses belajar dan pembelajaran siswa di kelas harus mengarah pada pembelajaran aktif berpusat pada siswa (student center). Baharudin dan Esa (2010) mengemukakan alasan digunakannya model pembelajaran problem solving, yaitu dapat mendidik siswa untuk berpikir secara sistematis, mampu mencari jalan keluar dari suatu kesulitan yang dihadapi, dan mendidik siswa percaya pada diri sendiri.

Untuk mengatasi semua kendala-kendala yang ada, terutama peningkatan hasil belajar siswa, maka pembelajaran Fisika di sekolah memerlukan model pembelajaran. Problem solving merupakan salah satu model pembelajaran yang dapat meningkatkan kemampuan siswa (Ristiasari, Priyono, \& Sukaesih, 2012) Pembelajaran fisika dapat dilakukan dengan berbagai model diantaranya adalah model pembelajaran problem solving berbasis demonstrasi. Model pembelajaran problem solving adalah pembelajaran dengan pemecahan masalah. Pada model pembelajaran ini, guru memberikan permasalahan sesuai dengan topik yang akan diajarkan, dan siswa diminta untuk menyelesaikan permasalahan tersebut. Model pembelajaran problem solving merupakan model pembelajaran yang memusatkan siswa cara menghadapi permasalahan dengan langkah penyelesaian yang sistematis yaitu dengan memahami masalah, menyusun rencana penyelesaian, melaksanakan perencanaan dan melihat kembali penyelesaian. Pada penelitian ini, penerapan model pembelajaran problem solving dikaitkan dengan demonstrasi. Demonstrasi diartikan sebagai metode mengajar dengan pendekatan visual agar siswa dapat mengamati proses, informasi, peristiwa, alat dalam pembelajaran fisika (Suparno, 2007). Tujuan sangat jelas agar siswa lebih memahami bahan yang diajarkan lewat suatu kenyataan yang dapat diamati agar lebih mudah mengerti. Dengan demikian, model pembelajaran problem solving berbasis demonstrasi yang dimaksud dalam penelitian ini diharapkan dapat dijadikan satu di antara 
model pembelajaran alternatif untuk meningkatkan hasil belajar siswa pada materi suhu dan pengukurannya di kelas VII SMP Torsina Singkawang.

Arikunto (2006) menyatakan bahwa hasil belajar meliputi tiga ranah yaitu: kognitif, efektif dan psikomotorik. Pada penelitian ini hanya mengkaji hasil belajar ranah kognitif saja. Hasil belajar ranah kognitif terdiri dari enam jenis perilaku, yaitu pengetahuan, pemahaman, penerapan, analisis, sintesis, dan evaluasi. Keenam jenis perilaku ini dikaitkan terhadap penerapan model pembelajaran probelm solving berbasis demonstrasi. Adapun teknik pengumpulan data menggunakan tes dan observasi. Tes yang diberikan berupa soal pre-test sebelum treatment dan post-test setelah treatment yang diberikan untuk melihat peningkatan hasil belajar siswa. Berdasarkan permasalahan tersebut, maka penelitian ini mengangkat judul "Penerapan Model Pembelajaran Problem Solving Berbasis Demonstrasi Terhadap Peningkatan Hasil Belajar Siswa pada Materi Suhu dan Pengukurannya di Kelas VII."

\section{METODE PENELITIAN}

Jenis penelitian ini adalah penelitian kuantitatif, sedangkan bentuk desain eksperimen yang digunakan pada penelitian ini adalah pre-experimental design. Desain penelitian ini adalah one group pre testpost test design yang dilaksanakan pada satu kelas sebagai kelas eksperimen. Pada desain ini terdapat pre test yang dilaksanakan sebelum diberikan perlakuan (Sugiyono, 2015), sedangkan post test dilaksanakan setelah treatment. Treatment (perlakuan) yang diberikan yaitu penerapan model pembelajaran problem solving berbasis demonstrasi pada materi suhu dan pengukurannya di kelas VII SMP Torsina Singkawang.

Dalam penelitian ini, tes yang digunakan untuk mengukur hasil belajar ranah kognitif fisika siswa adalah tes pilihan ganda (multiple choice test) sebanyak 10 soal tanpa reasoning. Tes pilihan ganda dalam penelitian ini, dilakukan untuk mengetahui hasil belajar ranah kognitif siswa pada pokok bahasan suhu dan pengukurannya. Lembar tes terlebih dahulu diuji tingkat validitas dan reliabilitasnya. Hasil tes siswa dianalisis menggunakan rumus Mean dan uji N-gain. Lembar respon siswa digunakan untuk mengetahui tanggapan siswa terhadap model pembelajaran problem solving berbasis demonstrasi yang telah diterapkan. Lembar respon ini berisi 10 pernyataan, yang terdiri dari lima pernyataan positif dan lima pernyataan negatif. Analisis hasil respon siswa menggunakan rumus persentase respon siswa.

\section{HASIL DAN PEMBAHASAN}

Pada penelitian ini ditemukan bahwa hasil rata-rata pre test dan post test siswa, diuraikan pada Tabel 1.

Tabel 1. Data Skor Rata-rata Pre Test dan Post Test Siswa

\begin{tabular}{cccc}
\hline No & Kode Siswa & Nilai Pre Test & Nilai Post Test \\
\hline 1 & A-01 & 20 & 60 \\
2 & A-02 & 30 & 70 \\
3 & A-03 & 30 & 70 \\
4 & A-04 & 50 & 70 \\
5 & A-05 & 30 & 50 \\
6 & A-06 & 20 & 80 \\
7 & A-07 & 60 & 80 \\
8 & A-08 & 40 & 80 \\
9 & A-09 & 40 & 70 \\
10 & A-010 & 20 & 70 \\
11 & A-011 & 40 & 60 \\
12 & A-012 & 40 & 70 \\
\hline
\end{tabular}




\begin{tabular}{lccc}
\hline No & Kode Siswa & Nilai Pre Test & Nilai Post Test \\
\hline 13 & A-013 & 50 & 70 \\
14 & A-014 & 30 & 60 \\
15 & A-015 & 60 & 60 \\
16 & A-016 & 50 & 80 \\
17 & A-017 & 40 & 80 \\
18 & A-018 & 50 & 70 \\
19 & A-019 & 30 & 60 \\
20 & A-020 & 20 & 70 \\
21 & A-021 & 20 & 70 \\
22 & A-022 & 40 & 80 \\
23 & A-023 & 50 & 70 \\
24 & A-024 & 30 & 70 \\
\hline Jumlah & & 890 & 1,670 \\
Rata-rata & & 38,69 & 72,60 \\
Nilai tertinggi & & 60 & 80 \\
Nilai terendah & & 20 & 50 \\
\hline
\end{tabular}

Berdasarkan Tabel 1 hasil rekapitulasi nilai rata-rata hasil pre tes dan post test siswa ditampilkan dalam bentuk diagram seperti pada Gambar 1.

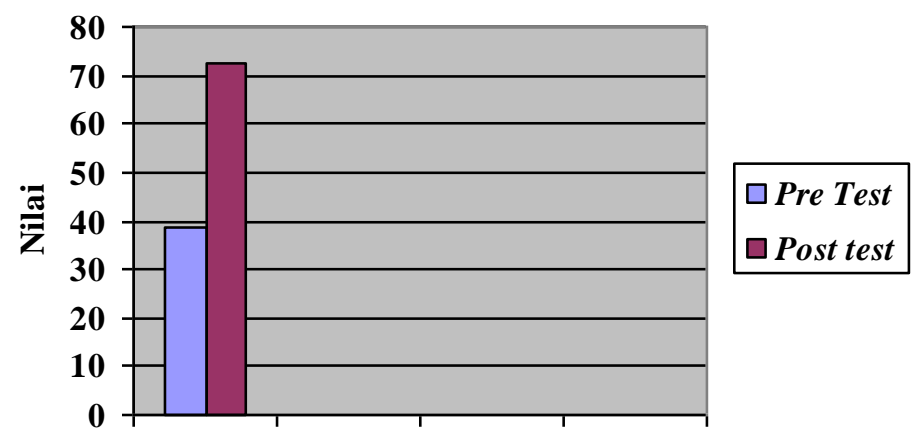

Hasil Belajar

Gambar 1. Hasil rekapitulasi nilai rata-rata pre test dan post test

Data peningkatan hasil belajar siswa diperoleh dari hasil skor rata-rata pre test dan skor rata-rata post test yang dinormalisasi dengan uji gain ternormalisasi. Berdasarkan perhitungan $\mathrm{N}$-gain dapat diungkapkan bahwa skor rata-rata hasil belajar siswa setelah dinormalisasi dengan uji $N$-gain diperoleh peningkatan nilai sebesar 0,55 , maka hasil belajar siswa diperoleh peningkatan dengan kategori sedang karena 0,55 berada pada $0,3 \leq N$-gain $<0,7$. Adapun hasil data respon siswa pada pernyataan positif dapat dilihat pada Tabel 2.

Berdasarkan Tabel 2, hasil data respon siswa pada pernyataan positif yaitu siswa yang memilih kategori S (Setuju) sebesar 80\%, jika diinterpretasikan respon siswa yang memilih kategori S maka memiliki kriteria baik. Untuk siswa yang memilih kategori TS (Tidak Setuju), sebesar 20\%, jika diinterpretasikan maka respon siswa yang memilih kategori TS memiliki kriteria sangat rendah. Adapun hasil data respon siswa pada pernyataan negatif dapat dilihat pada Tabel 3. 
Tabel 2. Data Respon Pernyataan Positif

\begin{tabular}{cccc}
\hline Nomor & \multicolumn{2}{c}{ Kategori Pernyataan } & \multirow{2}{*}{ Jumlah } \\
\cline { 2 - 3 } Pernyataan & S & TS & \\
\hline 1 & 20 & 4 & 24 \\
2 & 18 & 6 & 24 \\
3 & 20 & 4 & 24 \\
4 & 18 & 6 & 24 \\
5 & 20 & 4 & 24 \\
\hline Jumlah & 96 & 24 & 120 \\
Presentase (\%) & $80 \%$ & $20 \%$ & $100 \%$ \\
\hline
\end{tabular}

Tabel 3. Data Respon Pernyataan Negatif

\begin{tabular}{cccc}
\hline Nomor & \multicolumn{2}{c}{ Kategori Pernyataan } & \multirow{2}{*}{ Jumlah } \\
\cline { 2 - 3 } Pernyataan & S & TS & \\
\hline 6 & 9 & 15 & 24 \\
7 & 6 & 18 & 24 \\
8 & 4 & 20 & 24 \\
9 & 7 & 17 & 24 \\
10 & 4 & 20 & 24 \\
\hline Jumlah & 30 & 90 & 120 \\
Presentase (\%) & $25 \%$ & $75 \%$ & $100 \%$ \\
\hline
\end{tabular}

Berdasarkan Tabel 3, hasil data respon siswa pada pernyataan negatif yaitu diperoleh hasil perhitungan dari jawaban siswa yang memilih kategori S sebesar 25\%. Jika diinterpretasikan, maka respon siswa memiliki kriteria rendah. Untuk jawaban siswa yang memilih kategori TS sebesar $75 \%$, jika diinterpretasikan respon siswa memiliki kriteria cukup baik. Berdasarkan hal tersebut, setelah ditemukan peningkatan hasil belajar siswa yang masuk pada kategori sedang, dan respon siswa ditemukan positif, maka dapat disimpulkan bahwa Ho ditolak dan Ha diterima. Ho ditolak artinya Model pembelajaran problem solving berbasis demonstrasi tidak dapat dijadikan satu di antara model pembelajaran alternatif untuk meningkatkan hasil belajar siswa pada materi suhu dan pengukurannya di kelas VII, sedangkan Ha diterima artinya Model pembelajaran problem solving berbasis demonstrasi dapat dijadikan satu di antara model pembelajaran alternatif untuk meningkatkan hasil belajar siswa pada materi suhu dan pengukurannya di kelas VII. Hal ini berarti model pembelajaran problem solving berbasis demonstrasi dapat dijadikan satu di antara model pembelajaran alternatif untuk meningkatkan hasil belajar siswa pada materi suhu dan pengukurannya di kelas VII. Peningkatan hasil belajar ranah kognitif siswa merupakan perubahan yang ditimbulkan sebelum dan sesudah proses pembelajaran berlangsung (Richard, 1998).

Alat ukur berupa tes pilihan ganda yang telah diuji cobakan terlebih dahulu dengan reliabilitas dengan kategori tinggi. Analisis data hasil belajar siswa, diketahui skor rata-rata hasil post test lebih tinggi dibandingkan skor rata-rata hasil belajar pre test. Hal ini dapat dilihat dari perhitungan post test, diperoleh skor rata-rata post test sebesar 72,60 yang naik sebesar dari skor rata-rata pre test, yaitu sebesar 33,91 dari skor rata-rata pre test yaitu sebesar 38,69.

Apabila dikaji dari standar Kriteria Ketuntasan Minimal (KKM) pelajaran fisika sebesar 65,00 maka nilai rata-rata post test hasil belajar siswa telah mencapai standar KKM. Skor rata-rata hasil belajar siswa pada post test sebesar 72,60. Hal ini membuktikan bahwa model pembelajaran probelm solving berbasis demonstrasi dapat meningkatkan hasil belajar siswa pada materi suhu dan pengukurannya di kelas VII SMP Torsina Singkawang. Dengan model pembelajaran problem solving berbasis demonstrasi, siswa lebih aktif dalam membuktikan suatu konsep berdasarkan hasil pengamatan yang mereka lakukan sendiri. Keaktifan siswa dalam membuktikan suatu konsep, menjadikan pengetahuan yang mereka dapatkan menjadi jauh lebih bermakna. Akhirnya siswa menjadi lebih aktif dalam pembelajaran. Setelah proses belajar dengan model pembelajaran problem solving berbasis 
demonstrasi selesai, kepada siswa diberikan lembar respon untuk mengetahui tanggapan siswa selama proses pembelajaran berlangsung dengan penerapan model pembelajaran problem solving berbasis demonstrasi, siswa hanya memilih satu di antara dua kategori yang telah disediakan. Dari data yang diolah didapat presentase siswa pada pernyataan positif yang memilih kategori S (setuju) lebih besar dibanding kategori TS (tidak setuju), untuk persentase pernyataan negatif yang memilih kategori setuju lebih kecil dibanding kategori tidak setuju. Dengan demikian, dapat disimpulkan bahwa respon siswa tergolong positif berdasarkan data angket respon dengan menggunakan model pembelajaran problem solving pada materi suhu dan pengukurannya.

\section{KESIMPULAN}

Berdasarkan hasil pengelolaan data penlitian yang dilakukan, secara umum dapat disimpulkan bahwa model pembelajaran problem solving berbasis demonstrasi dapat dijadikan sebagai satu di antara model pembelajaran alternatif untuk meningkatkan hasil belajar siswa pada materi suhu dan pengukurannya di kelas VII. Secara khusus dapat disimpulkan beberapa hal sebagai berikut: (1) Skor rata-rata hasil belajar siswa sebelum dan sesudah diterapkan model pembelajaran problem solving berbasis demonstrasi pada materi suhu dan pengukurannnya di kelas VII berturut-turut adalah sebesar 38,69 dan 72,60. (2) Peningkatan hasil belajar siswa sesudah diterapkan model pembelajaran problem solving berbasis demonstrasi pada materi suhu dan pengukurannya di kelas VII adalah sebesar 0,55 dengan kriteria sedang. (3) Respon siswa pada penerapan model pembelajaran problem solving berbasis demonstrasi pada materi suhu dan pengukurannyan di kelas VII adalah positif.

\section{DAFTAR PUSTAKA}

Arikunto S. (2006). Prosedur Penelitian Suatu Pendekatan Praktik. Jakarta. Rineka Cipta.

Azizah, N., \& Edie, S. S. (2014). Pendekatan Problem Solving Laboratory Untuk Meningkatkan Kreatifitas dan Hasil Belajar Siswa Kelas XI MA Al Asror Gunung Pati Semarang. Unnes Physics Education Journal, 3(3), 28-33.

Baharudin, \& Wahyuni, E. N. (2010). Teori Belajar dan Pembelajaran. Yogyakarta: Ar-Ruzz Media.

Khoiri, A., Kusumawati, I., Kahar, M. S., \& Mursidi, A. (2019). Analysis of three representations in problem solving on additional relativistic velocities. Journal of Physics: Conference Series, 1153(1). https://doi.org/10.1088/1742-6596/1153/1/012136.

Permendiknas Nomor. 22 Tahun (2006). Standar Isi untuk Satuan Pendidikan Dasar dan Menengah. Jakarta.

Richard, R. (1998). Interactive-engagement versus traditional methods: A six-thousand-student survey of mechanics test data for introductory physics courses. American Journal of Physics, 1(68), 64-74. Retrieved from https://files.eric.ed.gov/fulltext/ED441679.pdf

Ristiasari, T., Priyono, B., \& Sukaesih, S. (2012). Model Pembelajaran Problem Solving Dengan Mind Mapping Terhadap Kemampuan Berpikir Kritis Siswa. Unnes Journal of Biology Education, $1(3), 34-41$.

Sugiyono. (2008). Metode Penelitian Pendidikan. Bandung: Alfabeta

Suparno, P. (2007). Metodologi Pembelajaran Fisika Konstruktivistik dan Menyenangkan. Yogyakarta. Universitas Sanata Dharma. 